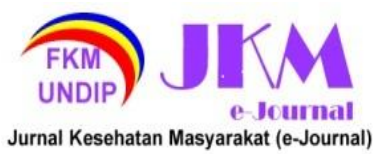

JURNAL KESEHATAN MASYARAKAT (e-Journal)

Volume 9, Nomor 6, November 2021

ISSN: 2715-5617 / e-ISSN: 2356-3346

http://ejournal3.undip.ac.id/index.php/jkm

\title{
ANALISIS POTENSI BAHAYA DENGAN MENGGUNAKAN METODE HIRA (HAZARD IDENTIFICATION AND RISK ASSESSMENT) PADA PABRIK ROTI TAWAR X BOYOLALI
}

\author{
Sekar Larasati ${ }^{*}$, Suroto ${ }^{2}$, Baju Widjasena ${ }^{2}$ \\ ${ }^{1}$ Peminatan Keselamatan dan Kesehatan Kerja Fakultas Kesehatan Masyarakat Universitas \\ Diponegoro JI. Prof. H. Soedarto, S.H.,Tembalang, Semarang, Indonesia \\ ${ }^{2}$ Bagian Keselamatan dan Kesehatan Kerja Fakultas Kesehatan Masyarakat Universitas Diponegoro \\ JI. Prof. H. Soedarto, S.H.,Tembalang, Semarang, Indonesia \\ ${ }^{*}$ Corresponding author : sekarlarasati.osh@gmail.com
}

\begin{abstract}
HIRA (Hazard Identification and Risk Assessment) is one of the risk assessment methods used to assess hazards that can pose the greatest risk taking into account how likely it is and how big an impact it is. This study was conducted to identify potential hazards, conduct risk assessments, and describe existing hazard control and provide recommendations on control efforts to reduce the risk of work accidents at the $X$ Boyolali Bread Factory. This research is qualitative research by conducting in-depth interviews with six main informants and making the HIRA table as a triangulation. The working process of this factory includes dough making, roasting, and packaging parts. Based on the research found several potential hazards, namely soreness or pain resulting from repeated movements, slippery floors, electrocution, exposed to a roasting machine, dehydration, exposure to peelers, and fire. Control efforts that have been carried out by the owner, namely engineering techniques on paring machines, providing information related to operational standards of work, the implementation of rest hours and holidays, as well as the provision of PPE to workers.
\end{abstract}

Keywords : HIRA, work environment, work process, hazard identification, risk assessment, control efforts

\section{PENDAHULUAN}

Keselamatan kerja merupakan sebuah proses perencanaan dan suatu pengendalian situasi yang memiliki potensi kecelakaan kerja menurut aturan dan prosedur yang diterapkan.

Pada data Badan Pusat Statistik (BPS) pada tahun 2019, penduduk yang berkerja di sektor informal sebanyak 74 juta jiwa atau setara dengan $57 \%$ dari penduduk Indonesia, sedangkan penduduk yang bekerja di sektor formal hanya 55,3 juta jiwa. ${ }^{2}$

Sektor informal dan formal dibedakan dengan adanya hubungan kerja atau kontrak kerja yang jelas. Pada umumnya sifat pekerjaan informal hanya berdasarkan pekerjaan dan perolehan upah sehingga masih rendahnya perlindungan $\mathrm{K} 3$ dan juga pengawasan pemerintah terhadap sektor informal. ${ }^{3}$

Industri roti merupakan salah satu sektor informal yang pekerjaannya dilakukan di rumah. Dalam proses produksi masih dikerjakan secara manual dengan melibatkan 3-5 orang pekerja. Dalam proses produksi biasanya masih kurang memenuhi metode, fasilitas, dan prinsip kerja yang baik.

Hazard Identification Risk Assessment (HIRA) adalah suatu metode yang digunakan sebelum melakukan suatu pekerjaan atau kegiatan. 4

Proses produksi yang dilakukan pada pabrik ini cukup kompleks meliputi, penimbangan dan pencampura bahan baku, penghalusan adonan dan pencetakan, pemanggangan adonan disuhu yang tinggi, pemotongan dan pengemasan roti tawar. ${ }^{5}$

Lingkungan kerja yang panas, serta keluhan-keluhan yang dirasakan para pekerja membuat peneliti tertarik untuk melakukan penelitian ini. Selain itu, seluruh proses pembuatan masih menggunakan alat yang sederhana dan dioperasikan manual oleh pekerja. ${ }^{6}$ Disetiap proses produksi memiliki potensi bahayanya masing-masing.

Penelitian salah satu pabrik roti tawar yang ada di Kabupaten Boyolali. Penelitian ini dilakukan untuk mengidentifikasi potensi bahaya, melakukan penilaian risiko, dan menggambarkan pengendalian bahaya yang sudah ada. Dengan diketahuinya potensi bahaya yang ada, peneliti dapat memberikan rekomendasi upaya pengendalian untuk mengurangi risiko kecelakaan kerja. 


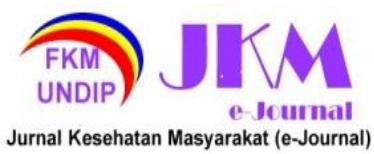

\section{METODE PENELITIAN}

Teknik pengumpulan data yang digunakan dalam penelitian ini adalah kualitatif yang bersifat observasional. Metode pengumpulan data yang digunakan peneliti adalah metode wawancara mendalam (indepth interview) dan menggunakan lembar observasi. Dalam masa pandemi Covid-19 saat ini, pengumpulan data dan observasi untuk pembuatan tabel HIRA dilakukan menggunakan sistem online.

Subjek penelitian adalah subjek yang dituju untuk diteliti oleh peneliti. Informan yang diteliti berjumlah 6 orang dengan kriteria lama bekerja minimal 1 tahun. Informan utama berjumlah 6 orang informan terdiri dari 5 orang pekerja dan 1 orang pemilik.

\section{HASIL DAN PEMBAHASAN}

Berdasarkan hasil observasi dengan menggunakan tabel dan hasil wawancara didapatkan beberapa hasil penelitian. Adapun hasil yang didapat antara lain :

1. Potensi Bahaya pada Pabrik Roti Tawar X BoyolaliBerdasarkan hasil penelitian ditemukan berbagai macam potensi bahaya pada proses kerja dan lingkungan kerja pabrik roti tawar.

a. Potensi bahaya pada proses pembuatan adonan

Beberapa potensi bahaya yang terdapat pada proses ini yaitu : lantai licin, gerakan berulang, mesin yang terkendala.

b. Potensi bahaya pada proses pembuatan adonan

Beberapa potensi bahaya yang terdapat pada proses ini yaitu : gerakan yang berulang dan monoton, serta tangan terjepit penggiling.

c. Potensi bahaya pada proses pemanggangan adonan

Beberapa potensi bahaya yang terdapat pada proses ini yaitu : gerakan berulang dan monoton, terkena alat pemanggang, ruangan yang panas, alat yang kadang memiliki kendala.

d. Potensi bahaya pada proses pendinginan roti

Beberapa potensi bahaya yang terdapat pada proses ini yaitu : gerakan berulang dan monoton.

e. Potensi bahaya pada proses pengemasan roti

Beberapa potensi bahaya yang terdapat pada proses ini yaitu : tangan masuk ke dalam alat pemotong roti, tangan terkena mesin pengupas roti, terkena pisau, gerakan berulang dan monoton. f. Penilaian risiko pada proses produksi Pabrik Roti Tawar X Boyolali.

Berdasarkan hasil penelitian dalam penilaian risiko dengan menggunakan matriks evaluasi risiko, didapatkan beberapa potensi bahaya yang memiliki tingkat risiko tinggi, tingkat risiko sedang, dan tingkat risiko rendah. Adapun hasil penilaian risiko ini merupakan hasil perkalian dari kemungkinan (probability) dengan keparahan (severity) pada pabrik roti tawar. ${ }^{8}$

Berikut merupakan hasil penilaian risiko yang diperoleh :

a. Lantai licin

Penyebab adanya kecelakaan kerja selanjutnya adalah terpelesetnya pekerja akibat kondisi lantai produksi yang licin. ${ }^{3}$ Potensi bahaya lantai licin memiliki nilai 4 , berasal dari nilai kemungkinan (probability) 2 dan keparahan (severity) 2 sehingga potensi bahaya ini masuk ke dalam kategori risiko tingkat rendah. Beberapa informan juga menjelaskan bahwa kondisi lantai licin disebabkan oleh dua hal yaitu oleh ceceran tepung, atau ceceran air yang digunakan saat pembuatan bahan adonan.

b. Gerakan berulang dan monoton

Sikap kerja yang tidak alamiah merupakan sikap kerja yang menimbulkan keadaan posisi tubuh jauh dari posisi alamiah, contohnya tangan diangkat, kaki diangkat, punggung membungkuk. ${ }^{9}$

Potensi bahaya gerakan berulang dan monoton terdapat pada seluruh proses produksi seperti dengan keterangan oleh informan gerakan berulang yang dimaksud di sini yaitu menarik adonan diproses penghalusan, memasukkan adonan ke dalam pemanggang dan mengangkat roti dari pemanggang, menyusun roti tawar pada proses pendinginan. Dalam hal ini yang membuat para pekerja mengeluhkan nyeri atau pegal pada bagian tertentu sehingga potensi bahaya ini memiliki nilai 12, berasal dari nilai kemungkinan (probability) 4 dan keparahan (severity) 3 dari jumlah tersebut potensi bahaya ini masuk ke dalam kategori risiko tingkat tinggi.

Hal ini sejalan dengan penelitian pada pekerja di Industri Geplak Bantul Yogyakarta, pada penelitian tersebut dihasilkan bahwa pekerja dengan posisi kerja berdiri dan membungkuk memiliki resiko 4,29 kali mengalami keluhan punggung bawah. ${ }^{10}$ 


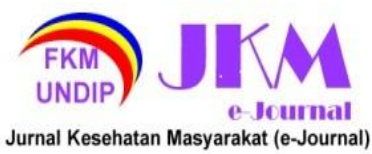

Keluhan yang disampaikan oleh para pekerja ini termasuk ke dalam kategori ringan karena tidak menyebabkan hilangnya hari kerja.

c. Alat atau mesin yang terkendala

Berdasarkan dari keterangan yang diberikan oleh informan alat atau mesin yang terkendala yaitu kendala yang ada pada proses pencampuran adonan dan proses pemanggangan, yang dapat menyebabkan pekerja tersengat aliran listrik dan juga kebakaran. Potensi bahaya ini terdapat di beberapa bagian proses produksi dan memiliki nilai 9 , berasal dari nilai kemungkinan (probability) 3 dan keparahan (severity) 3 dari jumlah tersebut potensi bahaya ini masuk ke dalam kategori risiko tingkat sedang. Hal ini sesuai dengan penelitian pada PT. Malindo Intitama Raya, pada penelitian tersebut menyebutkan bahwa kurangnya pengawasan pada potensi bahaya, maka dapat terjadi hubungan arus pendek ke lantai produksi sehingga mengakibatkan terganggunya proses produksi. ${ }^{11}$

d. Terjepit mesin penggiling

Potensi bahaya terjepit mesin penggiling memiliki nilai 6 , berasal dari nilai kemungkinan (probability) 2 dan keparahan (severity) 3 sehingga potensi bahaya ini masuk ke dalam kategori risiko tingkat sedang.

e. Terkena alat pemanggang

Potensi bahaya terkena lata pemanggang memiliki nilai 12 karena hal ini memang yang cukup sering dialami oleh para pekerja baru dan penilaian ini berasal dari nilai kemungkinan (probability) 4 dan keparahan (severity) 3 sehingga potensi bahaya ini masuk ke dalam kategori risiko tingkat tinggi.

f. Ruangan panas

Potensi bahaya bekerja di ruangan yang panas memiliki nilai 8 , berasal dari nilai kemungkinan (probability) 4 dan keparahan (severity) 2 sehingga potensi bahaya ini masuk ke dalam kategori risiko tingkat sedang. Dari keterangan yang diberikan oleh semua informan, mengeluhkan ruangan yang panas karena berdekatan dengan mesin pemanggang.

Hal ini sejalan dengan Suhu lingkungan yang panas dapat menyebabkan kelelahan, kantuk, meningkatkan kemungkinan kesalahan kerja. Semakin berat derajat kerja fisik, semakin besar beban metabolisme tubuh. Maka lebih banyak panas tubuh yang harus dikeluarkan dan stres pada suhu lingkungan akan semakin tinggi. ${ }^{12}$

g. Terkena mesin pemotong roti

Potensi bahaya terkena mesin pemotog roti memiliki nilai 6 , berasal dari nilai kemungkinan (probability) 2 dan keparahan (severity) 3 sehingga potensi bahaya ini masuk ke dalam kategori risiko tingkat sedang.

h. Terkena mesin pengupas roti

Potensi bahaya terkena mesin pengupas roti memiliki nilai 9 , berasal dari nilai kemungkinan (probability) 3 dan keparahan (severity) 3 sehingga potensi bahaya ini masuk ke dalam kategori risiko tingkat sedang.

i. Terkena pisau

Potensi bahaya terkena pisau memiliki nilai 3 , berasal dari nilai kemungkinan (probability) 3 dan keparahan (severity) 1 sehingga potensi bahaya ini masuk ke dalam kategori risiko tingkat rendah.

j. Pengendalian Potensi Bahaya yang dilakukan oleh Pabrik Roti Tawar X Boyolali

Untuk melakukan pengendalian risiko bahaya yang terdapat beberapa tahapan, tahapan yang digunakan sesuai dengan Hierarki Keselamatan dan Kesehatan Kerja (Hierarki K3) yaitu eliminasi, substitusi, rekayasa teknik, pengendalian administrasi, dan Alat Pelindung Diri. ${ }^{13}$

Berikut ini adalah beberapa upaya pengendalian yang telah dilakukan oleh Pabrik Roti Tawar X Boyolali:

a. Rekayasa teknik

Rekayasa teknik adalah pengendalian dengan cara mengubah struktur dari suatu objek kerja untuk mencegah paparan bahaya pada pekerja. ${ }^{11}$

Rekayasa teknik yang dilakukan pada Pabrik Roti Tawar X Boyolali ini sesuai dengan hirarki pengendalian yaitu dengan cara pemberian pelindung dibagian belakang alat pengupas roti. Akan tetapi bagian depan mesin masih terbuka sehingga dapat menyebabkan tangan terluka.

b. Pengendalian Administrasi

Pada pengendalian ini dilakukan dengan menyediakan sebuah system yang dapat mengurangi kemungkinan pekerja terpapar bahaya. ${ }^{7}$

Menurut keterangan dari wawancara yang dilakukan dengan informan upaya pengendalian administrasi yang dilakukan oleh pabrik ini dengan cara memberikan informasi terkait standar operasional kerja kepada para pekerja. Namun informasi yang 


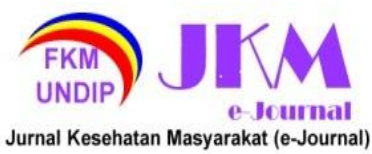

diberikan hanya dilakukan saat awal bekerja dan tidak dilakukan secara berkelanjutan, selain itu informasi yang diberikan masih belum cukup lengkap dan belum mencakup tentang K3 secara keseluruhan. Pemberlakuan jam istirahat dan hari libur bagi pekerja juga termasuk ke dalam pengendalian administrasi karena dengan upaya ini paparan bahaya pada pekerja dapat diminimalisir.

c. Pemberian Alat Pelindung Diri

Alat Pelindung Diri adalah pilihan terakhir dari Hierarki Pengendalian. Alat Pelindung Diri (APD) adalah suatu alat yang mempunyai kemampuan untuk melindungi seseorang yang fungsinya mengisolasi sebagian atau seluruh tubuh dari potensi bahaya ditempat kerja. ${ }^{14}$

Berdasarkan keterangan yang diberikan oleh informan, Alat Pelindung Diri yang diberikan berupa penutup kepala, sarung tangan, celemek, dan kaos lengan panjang yang digunakan sebagai seragam. Namun, penggunaan APD sendiri tidak diawasi sehingga masih memungkinkan untuk terjadinya potensi bahaya di tempat kerja.

\section{KESIMPULAN}

1. Terdapat potensi bahaya pada lingkungan kerja pada Pabrik Roti Tawar X Boyolali yaitu potensi bahaya lantai licin, lingkungan kerja berdebu, dehidrasi karena lingkungan kerja yang panas, dan kebakaran.

2. Terdapat potensi bahaya pada proses kerja Pabrik Roti Tawar X Boyolali antara lain : gerakan yang berulang, tersengat aliran listrik, terkena mesin pemanggang yang panas, terkena alat pengupas roti.

3. Berdasarkan penilaian risiko potensi bahaya yang ada pada Pabrik Roti Tawar X Boyolali didapatkan didapatkan beberapa potensi bahaya yaitu tingkat risiko rendah adalah lantai licin dan jari terkena pisau. Kemudian untuk risiko sedang yaitu tersengat aliran listrik, tangan terjepit mesin penggiling, ruangan yang panas, terkena mesin pemotong, terkena mesin pengupas roti. Sedangkan untuk tingkat risiko tinggi yaitu gerakan yang berulang atau monoton dan terkena mesin pemanggang.

\section{SARAN}

1. SOP yang sudah ada dapat dibuat secara tertulis, isi SOP dapat dilengkapi dengan informasi tentang keselamatan kerja, tidak hanya terkait dengan kualitas dan mutu produk.
2. Memberikan pelatihan dan menyediakan alat pemadam api sederhana guna mengantisipasi kebakaran.

3. Melakukan pengecekan alat lebih rutin dan secara teratur untuk menguragi risiko terjadinya kendala pada mesin yang digunakan.

4. Menyediakan tempat minum yang lebih dekat dengan area produksi sehingga lebih memudahkan pekerja untuk mengurangi potensi dehidrasi.

5. Memberikan pengawasan terhadap penggunaan APD di tempat kerja.

\section{DAFTAR PUSTAKA}

1. Undang-Undang Republik Indonesia No. 13 Tahun 2003. Undang-Undang Republik Indonesia No.13 Tahun 2003 tentang Ketenagakerjaan. Undang-Undang. 2003;(1):1-34. http://www.kemenperin.go.id/kompetensi/U U_13_2003.pdf

2. Badan Pusat Statistik dan Informasi. Angka Pekerja Sektor Informal Di Indonesia Tahun 2019.; 2019.

3. Hanifah F, Ekawati E, Jayanti S, Setyaningsih Y. Analisis Tingkat Risiko Ergonomi Menggunakan Metode Reba Terhadap Keluhan Msds Pada Pengrajin Batik Di Nisya Batik, Kuningan. J Kesehat Masy. 2017;5(2):106-112.

4. Mariawati AS, Umyati A, Andiyani F. Analisis Penerapan Keselamatan Kerja Menggunakan Metode Hazard Identification Risk Assessment (HIRA) Dengan Pendekatan Fault Tree Anlysis (FTA). Ind Serv. 2017;3c(1):293-300.

5. Sain MK, Meena ML. Occupational Health and Ergonomic Intervention in Indian Small Scale Industries: a Review. Int J Recent Adv Mech Eng. 2016;5(1):13-24.

6. Chen YL, Zhong YT, Liou BN, Yang CC. Musculoskeletal disorders symptoms among taiwanese bakery workers. Int J Environ Res Public Health. 2020;17(8). doi:10.3390/ijerph17082960

7. PUTRANTO NM, MARHAENDRA N. IDENTIFIKASI BAHAYA PEKERJAAN PADA DAERAHBERTEGANGAN SWITCHYARD $150 \quad \mathrm{kV}$ DENGANPENDEKATAN JOB SAFETY ANALYSIS (JSA) DANHAZARD IDENTIFICATION RISK ASSESSMENT AND RISKCONTROL (HIRARC) (Studi Kasus: PT. PJB Unit Pembangkitan Gresik). Undergrad Thesis, Occup Saf Heal Eng RSPP 658155 Put i, 2010. Published online 2010. Accessed December 22, 2020. 


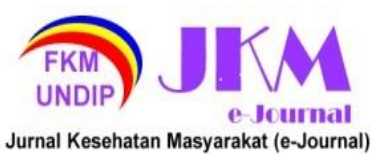

http://digilib.its.ac.id/ITS-Undergraduate3100010040958/14869

8. Australian/New Zealand Standard. Risk Management Guidlines.; 2004.

9. Rosyidin W. Analisis Potensi Bahaya Dengan Metode Hazard Identification And Risk Assessment (Hira) dan Job Safety Analysis (Jsa) (Studi Kasus: Pt.Kampung Coklat). Published online 2018.

10. Pujiono BN, Tama IP, Efranto RY ANALISIS POTENSI BAHAYA SERTA REKOMENDASI PERBAIKAN DENGAN METODE HAZARD AND OPERABILITY STUDY (HAZOP) MELALUI PERANGKINGAN OHS RISK ASSESSMENT AND CONTROL (Studi Kasus: Area PM-1 PT. Ekamas Fortuna). J Rekayasa dan Manaj Sist Ind. 2013;1(2):p253-263.

http://jrmsi.studentjournal.ub.ac.id/index.php /jrmsi/article/view/32

11. Kurniawati E, Sugiono, Yuniarti R. Springbed Dengan Metode Hazard Identification And Risk Assessment (Hira) (Studi Kasus: Pt. Malindo Intitama Raya, Malang, Jawa Timur) Analysis of The Potential of a Work Accidents On The Production Springbed Using by Hazard Identification and Risk. J Rekayasa dan Manaj Ind. 2014;2(1):11-23. http://jrmsi.studentjournal.ub.ac.id/index.php /jrmsi/article/view/56

12. Faktor $A$, Berhubungan $Y$, Kekambuhan $D$, Paru TB. Unnes Journal of Public Health. 2014;3(1):1-10.

13.Tarwaka. Keselamatan Dan Kesehatan Kerja: Manajemen Dan Implementasi K3 Di Tempat Kerja. Harapan Press; 2014.

14.UU RI Nomor 1 Tahun 1970 Tentang Keselamatan Kerja. Undang-undang Republik Indonesia Nomor 1 Tahun 1970 Tentang Keselamatan Kerja. Ann Rep vet Lab N Engl Zool Soc Chester Zool Gard. 1970;1970(5):unpaginated.
Volume 9, Nomor 6, November 2021

ISSN: 2715-5617 / e-ISSN: 2356-3346

http://ejournal3.undip.ac.id/index.php/jkm 